\title{
Article \\ Impact of the Restaurant Chimney Emissions on the Outdoor Air Quality
}

\author{
Mahmoud Fathy ElSharkawy *(i) and Osama Ahmed Ibrahim (D)
}

\author{
Department of Environmental Health, College of Public Health, Imam Abdul Rahman Bin Faisal University, \\ Dammam 34212, Saudi Arabia; olabib@iau.edu.sa \\ * Correspondence: msharkawy@iau.edu.sa
}

check for

updates

Citation: ElSharkawy, M.F.; Ibrahim,

O.A. Impact of the Restaurant

Chimney Emissions on the Outdoor

Air Quality. Atmosphere 2022, 13, 261.

https://doi.org/10.3390/

atmos13020261

Academic Editors: Begoña Artíñano, Manousos Ioannis Manousakas,

Anikó Angyal, Maria Gini and

Elena Hristova

Received: 17 December 2021

Accepted: 31 January 2022

Published: 3 February 2022

Publisher's Note: MDPI stays neutral with regard to jurisdictional claims in published maps and institutional affiliations.

Copyright: (c) 2022 by the authors. Licensee MDPI, Basel, Switzerland. This article is an open access article distributed under the terms and conditions of the Creative Commons Attribution (CC BY) license (https:/ / creativecommons.org/licenses/by/ $4.0 /)$.

\begin{abstract}
The emission of cooking fumes becomes a serious concern due to the fast development of the restaurant business because it harms the health of restaurant workers and customers and damages the outdoor air quality. This study was conducted to evaluate the impact of restaurant emissions on ambient air quality. Twenty restaurants with four different types of food cooking were selected in Dammam City, which represents a densely populated urban city in Saudi Arabia. Levels of five air pollutants were simultaneously measured in the restaurants' chimneys and in the surrounding ambient air. The highest mean levels of $\mathrm{CO}(64.8 \pm 44.3 \mathrm{ppm}), \mathrm{CO}_{2}$ (916.7 $\left.\pm 463.4 \mathrm{ppm}\right), \mathrm{VOCs}$ $(105.1 \pm 61.3 \mathrm{ppm}), \mathrm{NO}_{2}(4.2 \pm 2.4 \mathrm{ppm})$, and $\mathrm{SO}_{2}(8.0 \pm 7.4 \mathrm{ppm})$ were recorded in chimneys of the grilling restaurants. Similarly, the highest levels of all pollutants were recorded in the areas adjacent to the grilling restaurants rather than other types.
\end{abstract}

Keywords: restaurants; chimney emission; combustion efficiency; ambient air pollution; emission standards

\section{Introduction}

Worldwide, the cooking process consumes huge amounts of energy, especially in developing countries [1,2]. Several types of fuels are usually used for cooking including natural gas, charcoal, wood, kerosene, liquefied petroleum gas, electricity, biogas, and biomass [3,4]. Consequently, large amounts of harmful air pollutants and greenhouse gases are emitted daily during the cooking processes [5,6]. Restaurants represent the most important site for cooking where many local and foreign people tend to spend a lot of their time. The emission of cooking fumes has become more serious due to the fast development of the restaurant business [7]. The emitted pollutants from restaurants not only harm the health of restaurant workers and customers but also represent a great contributor to the outdoor air pollution levels [8-12]. Complaints against cooking fume/odor emissions from restaurants have been increasing and recorded in some areas of the world [13].

For several years, great concern has been given to the cooking fumes, particularly in the highly crowded cities where restaurants are usually located in densely populated areas that are very close to residential and other sensitive buildings [13]. Emission of pollutants from restaurants results from heating and cooking operations where several types of food are cooked and different types of fuels are used [14]. The amounts and composition of pollutants emitted from those sources depend greatly on the cooking materials, cooking styles, and even cooking fuel [15]. For example, charcoal is used extensively for barbecuing in most restaurants in the world because it has high heating value, is cheap compared to other types of fuels, can be easily stored, and gives a unique flavor and texture to the food [16-18]. Charcoal contains various types of organic and inorganic compounds such as hydrocarbons, sulfur, water, and oxygen along and numerous trace elements [19-21]. Therefore, the combustion of charcoal creates a considerable amount of airborne toxic elements both in the solid and gaseous states. The coal-tars and soot (fine black particulate matter) have been documented as human carcinogens since the 
late 1700s [22,23]. Several previous studies revealed that the combustion of charcoal is considered a potential source of volatile organic compounds (VOCs) and polycyclic aromatic hydrocarbon (PAHs) $[24,25]$ that have several adverse health effects including carcinogenicity in addition to its contribution to the formation of photochemical groundlevel ozone [26,27]. Sulfur-as a component of fuels that occurs primarily in coal, petrol, kerosene, and diesel — can produce sulfur dioxide gas $\left(\mathrm{SO}_{2}\right)$ when combusted during the cooking process or any high-temperature combustion. The presence of $\mathrm{SO}_{2}$ in the air leads to irritations of the mucous membranes and the eyes, as well as chronic bronchitis [28]. Combustion of charcoal is also considered a source of carbon monoxide (CO) in the air [29] that is considered a chemical asphyxiant for humans [30]. The other cooking activities in restaurants, such as charbroiling, frying, and baking, are also considered sources of the same or different air pollutants that make significant contributions to both indoor and outdoor air pollution [31,32].

Unfortunately, a lot of the exhaust outlets of ventilation ducting systems in restaurants are always not located at favorable locations, in particular in densely populated urban regions near the sensitive receptors, such as residential premises, schools, or clinics [13]. Effective control measures should be taken from the formal governmental agencies with the cooperation of owners and operators of the restaurants to ensure that no visible cooking fumes nor objectionable odor would be emitted causing any harm or forms of pollution. In this regard, appropriate high-performance air pollution control equipment must be installed at the kitchen ventilation system of the food premises for treating cooking fume emissions before being discharged to the outdoor environment as well as it is considered a cost-effective way to reduce indoor air pollution and the related health problems $[33,34]$. As a general guideline, the control equipment of the restaurant must be installed directly above the stoves and cooking appliances and properly connected with the exhaust ducts to prevent cooking fume from leaking through possible cracks. Moreover, the ducts must be connected with exhaust fans of adequate capacity [35]. The range hood is one of the most common types of ventilation [36]. It has the advantage of providing constant ventilation for the smoke to escape [37]. The more effective type of cooker-hood is the one that extracts the contaminated air from the cooking zone and ejects it to the ambient environment [38]. Chimneys, that must be extended to above the roof of the restaurant, are more effective because they largely prevent the smoke from entering the kitchen or any other internal site of the restaurant $[39,40]$. Additionally, the chimney plays an active role in the performance of the stove and in reducing emissions by influencing the overall air-to-fuel ratio and subsequently the production of $\mathrm{CO}$ and/or particulate matter (PM) [41]. Additionally, chimneys keep flue gas separated from ambient conditions, providing a longer residence time of the gas within a heated environment [42].

Numerous previous studies have been conducted concerning the impact of cooking emissions on the indoor environment of restaurants in developed and developing countries [43-45]. Despite their importance, data on the impact of cooking emissions on the direct surrounding environment and air pollution levels are still very scarce. This study was conducted to fill this gap by studying the impact of the restaurant emissions on the outdoor ambient air pollution in a densely populated urban city representing a developing country. It was conducted to quantify emissions of different pollutants from the chimneys of various restaurants and simultaneously levels of the same pollutants in the ambient air. It was aiming also to guide the owners and operators of restaurants, food businesses, and corresponding governmental agencies in helping them understand and apply the best practical control measures to minimize these emissions, thereby preventing air pollution problems.

\section{Materials and Methods}

\subsection{Study Area and Period}

This study was conducted in Dammam City in the Eastern province of the Kingdom of Saudi Arabia (KSA). Generally, KSA is characterized by the presence of a wide variety and 
large number of restaurants in all cities, particularly those with high dense populations or visitors such as Mecca, Riyadh, and Dammam because of the large numbers of immigrants, foreign workers, and people visiting the country to perform Hajj and Omrah. Dammam is considered one of the most important cities in the Kingdom. It is the capital, the major seaport, and one of the most populated cities in the Eastern Province of KSA. It is also a major administrative center for the Saudi oil industry (Aramco) and about $40 \%$ of the industrial activity of KSA is located in it. There is an increase in the migration of people to Dammam city for obtaining jobs and studying because of the presence of a large number of industries, universities, and different governmental centers. Due to the rapid population growth in the city, there is an increasing demand for food and, consequently, the number of restaurants is also increasing. All restaurants in Dammam are located close to the residential premises, schools, hospitals, and other sensitive receptors.

A variety of cooking methods are used in restaurants, but it differs from one to another according to the type of food that characterizes each restaurant. For example, the main cooking methods of some restaurants include stir frying, simmering, steaming, roasting, smoking, and stewing, while in other restaurants the main cooking methods are grilling, broiling, and deep frying. Twenty restaurants were selected in Dammam for this study representing four different types of food cooking; grilling (such as chicken or meat grilled on charcoal), frying (such as fried chicken), cooking (such as cooked rice and vegetables), and baking (such as pizza and pastry). Five restaurants from each type were selected and the twenty restaurants were contributed to the same criteria and specifications, except the type of food cooking. All selected restaurants were located on the ground floor of a residential building of 3-4 floors with a chimney extended to above the building roof. They are installed in densely populated areas adjacent to moderate traffic activity streets (about $500 \mathrm{cars} / \mathrm{h}$ ) and far from any other air pollution sources such as industrial activity or any other restaurants. All restaurants have nearly the same size and number of cooking appliances. The objective of this selection was to remove any factor that could affect the results of a comparison between the emission of pollutants from the restaurants' chimneys and the ambient levels of the same pollutant. For confidence, confirmation, and comparison, a building with the same characteristics was selected in an area far from any restaurants but with the same traffic activity. This area was considered a "control area".

Climatically, Dammam has a hot desert climate. The winter temperatures range from mild to warm, while the summer temperatures are extremely hot, usually exceeding $40{ }^{\circ} \mathrm{C}$ $\left(104^{\circ} \mathrm{F}\right)$ for about six months. Rainfall in Dammam is generally sparse and usually occurs in small amounts in December. Heavy thunderstorms are not uncommon in winter. For this reason, this study was conducted during the six warm and hot months (April-August) of the year 2019.

\subsection{Measurement of Chimney Emissions}

The cooking fumes of all selected restaurants were extracted through an exhaust hood and then discharged into the atmosphere near the surrounding neighbors. Owners of restaurants did not want to make a hole in the chimney. Therefore, the sampling probe was placed directly near the outlet center of the outdoor chimney and paralleled with the direction of the chimney. Generally, for measuring the quality of the combustion of the cooking tools, the probe of a flue gas analyzer (electronic sensor) was applied to the cooking tool chimney where levels of gaseous pollutants can be measured directly on site. The advantage of the electronic sensors is that they can be used for a long time and their usage lies in real-time measurement. The air pollution content is determined using sensors where there are whole ranges of measuring principles that can be employed such as flame or photo-ionization detection for organic species, chemiluminescence for oxides of nitrogen, non-dispersive infrared for carbon monoxide, Fourier transform infrared for sulfur dioxide, etc. A digital readout indicates the measured value at the spot. These devices need to be calibrated before each monitoring session. The calibration occurs through a test gas of known pollutant concentration [42]. 
During our study, the Lancom 4 Portable Flue Gas Analyzer was used for measuring levels of combustion gases and cooking vapors in the exhaust chimneys of all restaurants. This analyzer meets the US EPA CTM 034 reference method, and it has data acquisition and analysis software. The analyzer is composed of a monitor, a probe hose of $3 \mathrm{~m}$ length, and a probe pipe of $0.3 \mathrm{~m}$ length. Its monitor can read up to 17 measurement parameters and it is a useful tool to observe trends. Moreover, it is free from any bias that can be caused by substances in the waste gas. The measurement specifications of this analyzer are illustrated in Table 1. The Quality Management System of Land Instruments International is approved to BS EN ISO 9001 for the design, manufacture, and on-site servicing. For quality assurance and quality control (QA/QC), the analyzer was recently calibrated by the manufacturer themselves with a certificate of conformity and calibration No. 21572853, and calibration before and after measurement using standards that are traceable to certified reference materials was conducted. Carbon dioxide $\left(\mathrm{CO}_{2}\right)$, carbon monoxide $(\mathrm{CO})$, nitrogen dioxide $\left(\mathrm{NO}_{2}\right)$, and sulfur dioxide $\left(\mathrm{SO}_{2}\right)$ were representing the combustion gases, while the volatile organic compounds (VOCs) were representing cooking vapors. Concentrations of these five pollutants were measured in parts per million (ppm). The exhaust measurements were carried out at least twice during the peak cooking period. A real-life photograph of the sampling setup while sampling was being undertaken is shown in Figure 1.

Table 1. Measurement specifications of the Lancom 4 Portable Flue Gas Analyzer.

\begin{tabular}{|c|c|c|c|c|}
\hline Sensor & Detection Limit & $\begin{array}{c}\text { Full Scale } \\
\text { Range }\end{array}$ & $\begin{array}{c}\text { Upscale } \\
\text { Repeatability }\end{array}$ & Resolution \\
\hline $\mathrm{O}_{2}$ & $0.2 \%$ & 0 to $30 \% v / v$ & $\pm 1 \%$ & $0.1 \% v / v$ \\
\hline CO (low) & $2 \mathrm{ppm}$ & 0 to $6000 \mathrm{ppm}$ & CO (low) & $2 \mathrm{ppm}$ \\
\hline CO (high) & $20 \mathrm{ppm}$ & 0 to $10 \%$ & $\pm 2 \%$ * & $0.1 \mathrm{ppm}$ \\
\hline $\mathrm{SO}_{2}$ & 2 ppm & 0 to $4000 \mathrm{ppm}$ & $\pm 2 \%$ * & $0.1 \mathrm{ppm}$ \\
\hline $\mathrm{NO}$ & 2 ppm & 0 to $5000 \mathrm{ppm}$ & $\pm 2 \%$ * & $0.1 \mathrm{ppm}$ \\
\hline $\mathrm{NO}_{2}$ & 2 ppm & 0 to $1000 \mathrm{ppm}$ & $\pm 2 \%$ * & $0.1 \mathrm{ppm}$ \\
\hline $\begin{array}{l}\text { Hydrocarbons } \\
\qquad\left(\mathrm{C}_{\mathrm{x}} \mathrm{H}_{\mathrm{y}}\right)\end{array}$ & $\begin{array}{l}\text { (Application } \\
\text { dependent) }\end{array}$ & 0 to $5 \% v / v$ & $\pm 4 \% *$ & $0.1 \% v / v$ \\
\hline $\begin{array}{c}\text { Flue Gas / Ambient } \\
\text { Temperature }\end{array}$ & \multicolumn{4}{|c|}{ Measured } \\
\hline Draft & \multicolumn{4}{|c|}{ $\pm 50 \mathrm{hPa} / 20$ "Water Gauge" } \\
\hline Flow (velocity) & \multicolumn{4}{|c|}{1 to $50 \mathrm{~m} / \mathrm{s}$} \\
\hline
\end{tabular}

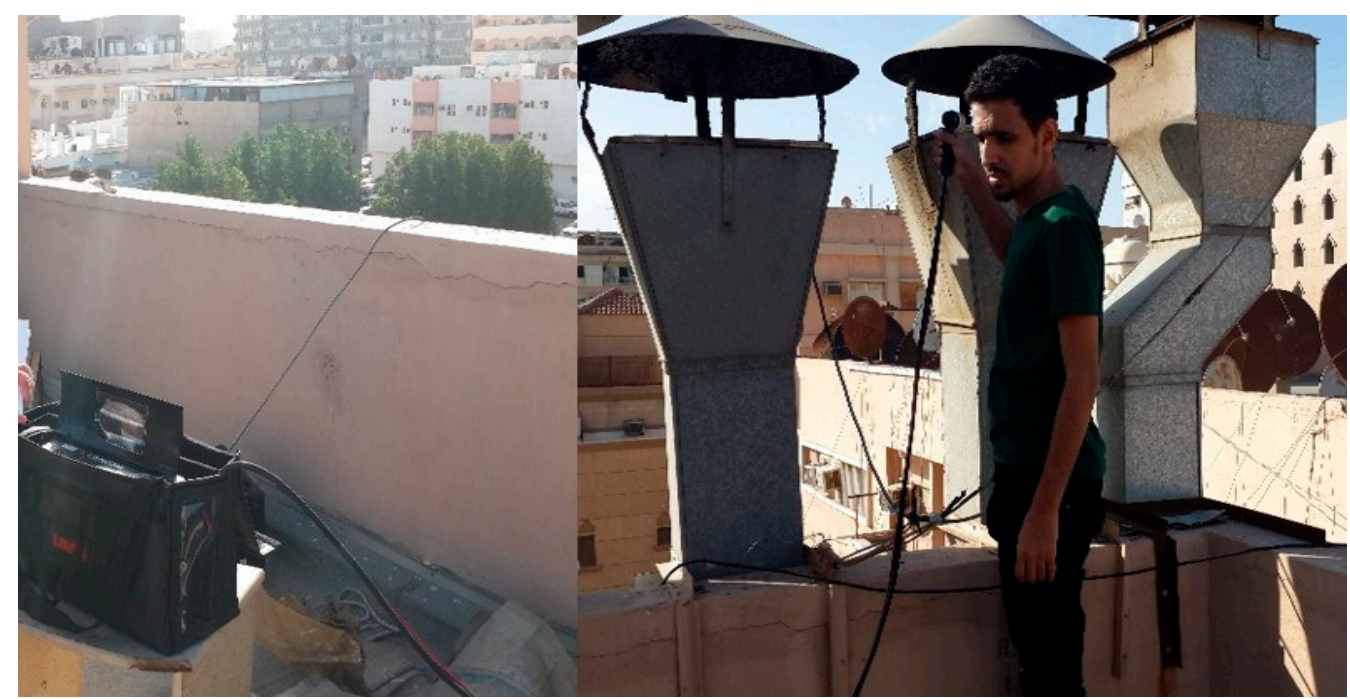

Figure 1. A real-life photograph of the sampling setup (authors personal contribution). 
For each one of the four types of restaurants (grilling, frying, cooking, and baking), the measurements were conducted for inside all chimneys of each restaurant that were installed on the restaurant's building roof and simultaneously from the ambient air outside the stack. Some restaurants have only one chimney while others have two chimneys. For each chimney, at least three measurements for each pollutant were performed for $2 \mathrm{~h}$. Each one of the 20 selected restaurants was visited twice, and the monitoring process was performed during the evening period because this period represents the rush hours and maximum activity of cooking and food preparation inside each type of restaurant.

\subsection{Measurement of Outdoor Ambient Air Pollution}

Simultaneously with the chimney measurements, levels of the same pollutants in the outdoor air were measured at 10-20 m from the chimney in the downwind direction to study the effect of emitted pollutants in the ambient air levels. The selection of this distance was based on the actual presence of inhabitants' rooms on the residential building roof at $10 \mathrm{~m}$ from the chimney in some of the selected restaurants' buildings. The above five air pollutants were directly measured by the Gray Wolf's DirectSense ${ }^{\circledR}$ (Shelton, CT, USA) mobile PC-based products, AdvancedSense ${ }^{\mathrm{TM}}$ (Shelton, CT, USA) meters, and Wolf Pack ${ }^{\mathrm{TM}}$ (Shelton, CT, USA) area monitor. This monitor is composed of multi-gas detectors, and it is equipped with a wireless radio frequency modem that allows the unit to communicate and transmit readings and other information on a real-time basis with a remotely located base controller. Reliably measure key specific pollutants (VOCs, $\mathrm{CO}, \mathrm{O}_{3}, \mathrm{NO}_{2}, \mathrm{NH}_{3}, \mathrm{HCHO}$, etc.; choose from $25+$ gas sensors), as well as particulate, ventilation rates $\left(\mathrm{CO}_{2}\right.$ and airflow), differential pressure (DP), and more. High-performance, fast-response instrumentation for consistent use over portable, long-term, and continuous testing applications. In stand-alone operation, it is a rugged, weather-resistant, portable monitor that can run over $24 \mathrm{~h}$ on either rechargeable lithium-ion or alkaline batteries. The probe dimensions are 2 in. $(5 \mathrm{~cm})$ diameter $\times 12.5 \mathrm{in}$. $(30 \mathrm{~cm})$ length. Concentrations of the five pollutants were also measured in ppm. The measurement specifications of this gas detector are illustrated in Table 2. For quality assurance and quality control $(\mathrm{QA} / \mathrm{QC})$, the detector was recently calibrated by the manufacturer with a certificate of conformity and calibration No. 03-1291. Similarly, for each measuring point in the ambient around the chimney, at least three measurements for each pollutant were undertaken for $2 \mathrm{~h}$.

Table 2. Measurement specifications of the Gray Wolf's DirectSense Gas Detector.

\begin{tabular}{ccccc}
\hline Parameter & Range & Limit of Detection & $\begin{array}{c}\text { T90 } \\
\text { Response }\end{array}$ & $\begin{array}{c}\text { Sensor } \\
\text { Drift }\end{array}$ \\
\hline $\mathrm{SO}_{2}$ & $0-20.0 \mathrm{ppm}$ & $0.2 \mathrm{ppm}$ & $<25 \mathrm{~s}$ & $<2 \%$ per mo \\
\hline $\mathrm{NO}_{2}$ & $0-20.0 \mathrm{ppm}$ & $0.1 \mathrm{ppm}$ & $<20 \mathrm{~s}$ & $<2 \%$ per mo \\
\hline $\mathrm{NO}$ & $0-200 \mathrm{ppm}$ & $1 \mathrm{ppm}$ & $<20 \mathrm{~s}$ & $<2 \%$ per mo \\
\hline $\mathrm{CO}$ & $0-500 \mathrm{ppm}$ & $1 \mathrm{ppm}$ & $<35 \mathrm{~s}$ & $<2 \%$ per mo \\
\hline $\mathrm{CO}_{2}$ & 0 to $10,000 \mathrm{ppm}$ & $\pm 3 \% \mathrm{rdg} \pm 50 \mathrm{ppm}$ & $<25 \mathrm{~s}$ & $<2 \%$ per mo \\
\hline $\mathrm{TVOCs}$ & 0 to $10,000 \mathrm{ppm}$ & $0.1 \mathrm{ppm}$ & $<25 \mathrm{~s}$ & $<2 \%$ per mo \\
\hline
\end{tabular}

\subsection{Measuring of Meteorological Factors}

So far as the dispersion of pollutants from a chimney is concerned, temporal wind distribution is the most important factor for the concentration buildup of air pollutants in the surrounding air basin. The most important meteorological condition in this study was the prevailing wind at the time of measurement in the study area. Before conducting any measurements, the prevailing wind direction was recorded by the Kestrel 4500 electronic weather station (Kestrelmeters, Boothwyn, PA, USA). This tool calculates crosswind and headwind/tailwind regarding a user-set target heading and stores the information along with all the other environmental readings in its 1400 data point memory. The smoke exhaust 
is mixed fast with ambient air, in which high temperature and relative humidity (RH) is not a major issue in the measurements. However, wind speed, temperature, and RH were also measured by the same tool.

\section{Results and Discussion}

\subsection{Chimney Emissions}

Figure 2 represents the mean levels of the measured air pollutants in the chimney exhaust of the four methods of food cooking (grilling, frying, cooking, and baking). The highest levels of all pollutants were emitted from the grilling chimneys followed by frying and baking while the lowest levels were emitted from the cooking ones. Inside the grilling chimneys, the highest mean levels \pm standard deviation (SD) of $\mathrm{CO}, \mathrm{CO}_{2}, \mathrm{VOCs}, \mathrm{NO}_{2}$, and $\mathrm{SO}_{2}$ were $(64.8 \pm 44.3 \mathrm{ppm}),(916.7 \pm 463.4 \mathrm{ppm}),(105.1 \pm 61.3 \mathrm{ppm}),(4.2 \pm 2.4 \mathrm{ppm})$, and $(8.0 \pm 7.4 \mathrm{ppm})$, respectively, while in the cooking chimneys the lowest mean levels were $(8.3 \pm 4.4 \mathrm{ppm}),(555.2 \pm 108.7 \mathrm{ppm}),(17.7 \pm 7.1 \mathrm{ppm}),(1.4 \pm 0.6 \mathrm{ppm})$, and $(1.2 \pm 1.0 \mathrm{ppm})$, respectively. In most restaurants, food is prepared under high temperatures when grilled or fried whereas most fire-based cooking is based on the combustion of various fuel types (e.g., coal, natural gas, liquefied petroleum gas (LPG), and electrical energy) $[3,46]$. The most important chemical processes during the high-temperature treatment of food are the degradation of sugars, pyrolysis of proteins and amino acids, and the degradation of fats [44]. Several previous studies reported that the burning of charcoal is the major source of emission of air pollutants and offensive odorants in the atmosphere [16,20,47]. For example, a recent study was conducted to quantify and characterize the gaseous emissions from charcoal combustion in a brick barbecue grill revealed that emissions of $\mathrm{CO}, \mathrm{CO}_{2}$, $\mathrm{NOx}$, acid gases, $\mathrm{NH}_{3}$, and VOCs from the combustion of charcoal were higher than those of the other fuels and appliances [16]. Another study which was conducted in Portugal to assess levels of VOCs in the exhaust stacks on the roofs of a university canteen and a charcoal-grilled chicken restaurant concluded that the cooking fumes of the barbecued chicken contribute to emissions of VOCs higher than those of the university canteen [16]. Although the frying pan is different from the charcoal-burner, it can be used to heat food for high temperatures, and consequently, excess air pollutants, such as PM, CO, and VOCs, are released in the atmosphere. Numerous previous studies revealed that emission of pollutants from frying food on a hot steel pan and broiling food on steel bars above a charcoal burner was always higher than those of any other methods of cooking $[12,48,49]$. The results of my study are quite like most of these studies.

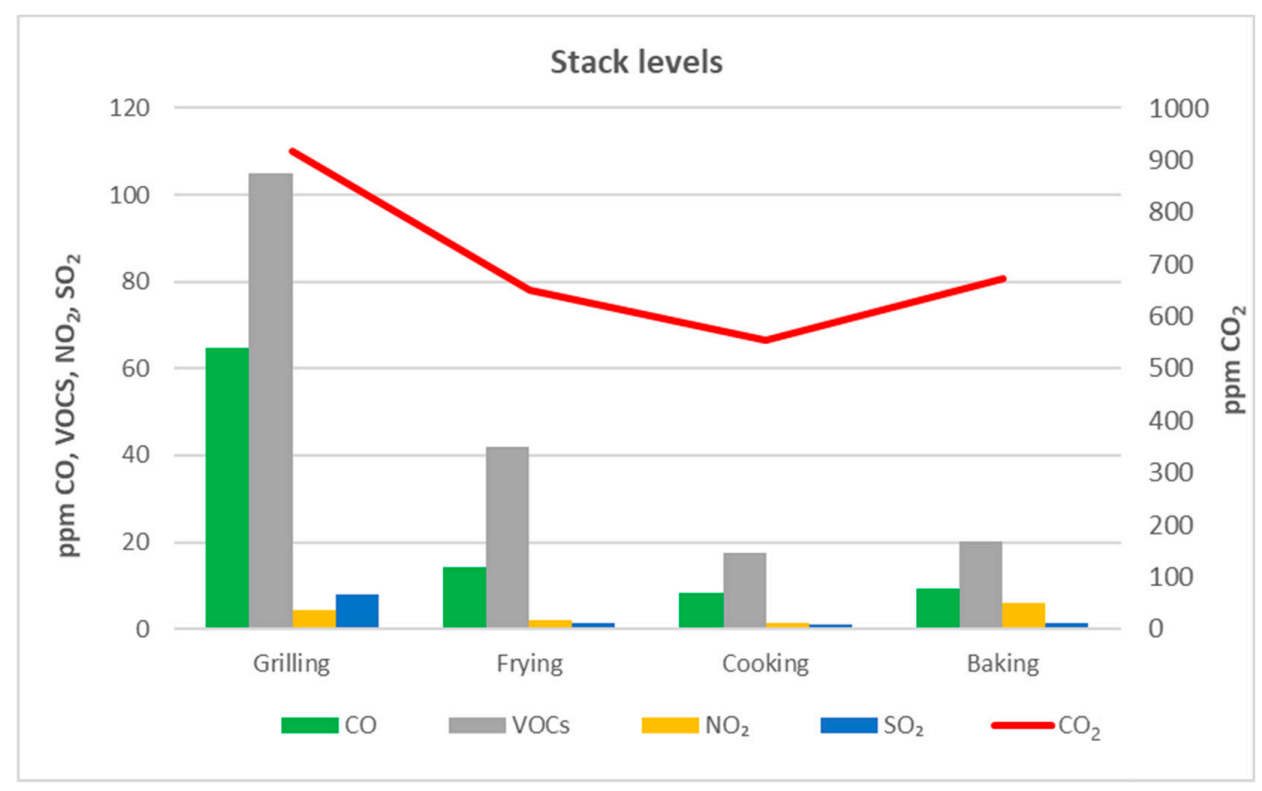

Figure 2. Mean levels of air pollutants in different restaurant chimneys. 
Combustion efficiency is influenced by the fuel quality and the combustion chamber characteristics of a stove. A simple determination of the combustion efficiency can be conducted with the calculation of the $\mathrm{CO} / \mathrm{CO}_{2}$ ratio. It is known that the mass of pollutants can be related to the mass of burnt fuel or the ratio between $\mathrm{CO}$ and $\mathrm{CO}_{2}$. The value of 0.1 or lower for this ratio is a good indication of the combustion efficiency [28]. In the present study, the $\mathrm{CO} / \mathrm{CO}_{2}$ for grilling, frying, cooking, and baking was $0.071,0.022,0.015$, and 0.013 , respectively, which reflects the good quality of combustion chambers in all selected restaurants.

Applying the independent t-test for comparing statistically between means of pollutants, indicated that there is a significant difference $(p<0.05)$ between mean levels of all pollutants, except $\mathrm{CO}_{2}$, emitted from grilling and the other three methods of cooking. As for $\mathrm{CO}_{2}$, there is a significant difference $(p<0.05)$ between grilling and both frying and cooking, while there is no significant difference $(p>0.05)$ between grilling and baking. The presence of the absence of statistical differences for the other three methods differs from one pollutant to another as shown in Table 3. This means that the emission of air pollutants from the grilling process is much higher than those of the other cooking methods, and it reflects the great contribution of the grilling process in emitting air pollutants from restaurants with comparing to other types of food cooking.

Table 3. Independent $t$-test for mean levels of pollutants in chimney exhaust.

\begin{tabular}{ccccc}
\hline Pollutant & Food Preparation Type & Frying & Cooking & Baking \\
\hline \multirow{2}{*}{$\mathrm{CO}$} & Grilling & $0.000^{*}$ & $0.000^{*}$ & $0.005^{*}$ \\
& Frying & & $0.023^{*}$ & 0.146 \\
& Cooking & & & 0.943 \\
\hline \multirow{2}{*}{$\mathrm{CO}_{2}$} & Grilling & $0.027^{*}$ & $0.008^{*}$ & 0.252 \\
& Frying & & 0.193 & 0.760 \\
& Cooking & & & 0.236 \\
\hline \multirow{2}{*}{$\mathrm{VOCs}$} & Grilling & $0.002^{*}$ & $0.000^{*}$ & $0.003^{*}$ \\
& Frying & & $0.000^{*}$ & $0.004^{*}$ \\
& Cooking & & 0.899 \\
\hline \multirow{2}{*}{$\mathrm{NO}_{2}$} & Grilling & $0.008^{*}$ & $0.002^{*}$ & $0.035^{*}$ \\
& Frying & & 0.444 & $0.000^{*}$ \\
& Cooking & & $0.017^{*}$ \\
\hline & Grilling & $0.001 *$ & $0.001 *$ & $0.049^{*}$ \\
$\mathrm{SO}_{2}$ & Frying & & 0.970 & 0.947 \\
& Cooking & & & 924 \\
\hline
\end{tabular}

${ }^{*}$ The mean difference is significant at the 0.05 level.

Unfortunately, there are no emission standards for restaurants' chimneys. The emission standards promulgated in the U.S. by the EPA, Europe, and some countries of Asia are standards intended to control air pollution from several industries [50-53]. From these standards, we selected the nearest industries to restaurants such as coal-fired power plants and municipal waste combustors (MWCs) to compare the results of my study. The purpose of this comparison is a trial to set a range of safe limits for protecting people's health against restaurant fumes. Table 4 indicates the results of our study compared with the selected emission standards for only three pollutants: $\mathrm{CO}, \mathrm{NO}_{2}$, and $\mathrm{SO}_{2}$. I did not find any standards for VOCs and $\mathrm{CO}_{2}$ for the same industries. All mean levels of my study were much lower than the selected standards. 
Table 4. Mean levels of pollutants in chimneys compared to emission standards.

\begin{tabular}{cccccc}
\hline \multirow{2}{*}{ Pollutant } & \multicolumn{4}{c}{ Mean Concentration of the Study $(\mathbf{p p m})$} & \multirow{2}{*}{ Standard (ppm) } \\
& Grilling & Frying & Cooking & Baking & Stan \\
\hline $\mathrm{CO}$ & 64.8 & 14.3 & 8.3 & 9.3 & 100 \\
$\mathrm{NO}_{2}$ & 4.2 & 2.0 & 1.4 & 6.0 & $50-150$ \\
$\mathrm{SO}_{2}$ & 8.0 & 1.4 & 1.2 & 1.3 & $30-80$ \\
\hline
\end{tabular}

\subsection{Outdoor Air Quality}

Figure 3 represents mean levels of air pollutants in the outdoor air at the surrounding areas of the selected chimneys, in addition to the control area. Similarly, with the chimneys results, the highest levels of $\mathrm{CO}(5.4 \pm 1.4 \mathrm{ppm}), \mathrm{CO}_{2}(427.1 \pm 86.8 \mathrm{ppm})$, VOCs $(0.31 \pm 0.23 \mathrm{ppm}), \mathrm{NO}_{2}(0.044 \pm 0.029)$, and $\mathrm{SO}_{2}(0.18 \pm 0.07 \mathrm{ppm})$ were emitted from the grilling chimneys followed by frying and baking while the lowest levels were emitted from the cooking chimneys. It is shown that Figure 2 has completely the same trend as Figure 1, which indicates the direct effect of restaurant chimney exhaust in the adjacent outdoor air quality levels. It can be confirmed by the lowest levels of all pollutants that were recorded in the control area as shown in Figure 2. This means that any negative or positive change in the combustion efficiency or the internal cooking process of any restaurant will be accompanied by the same change in the outer atmosphere. No doubt, this conclusion will help the decision-makers and regulators to effectively inspect the cooking emissions from restaurants.

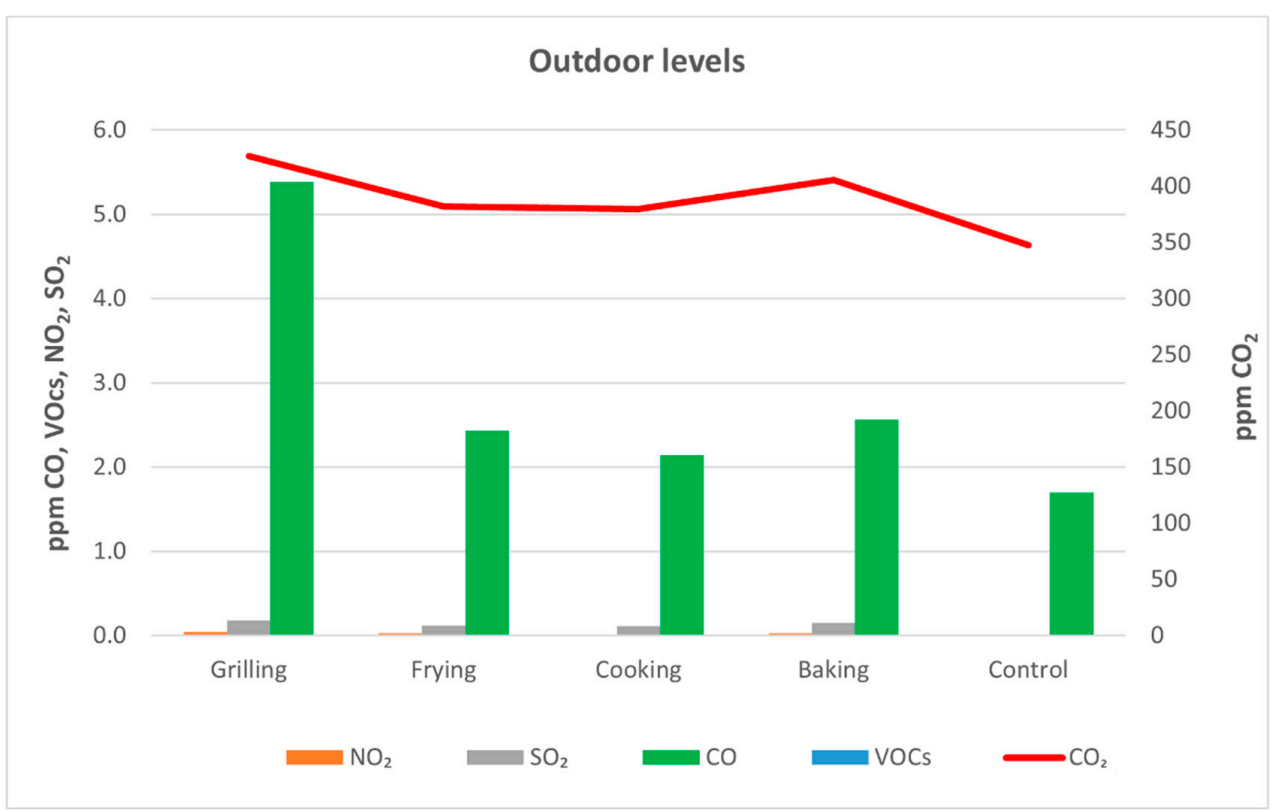

Figure 3. Mean levels of air pollutants in the surrounding areas outdoor of restaurants.

Statistically, the one-way ANOVA test was used to compare means of pollutants at the outdoor air for the four types of chimneys and the control area as shown in Table 5. Similarly, and surprisingly there is nearly the same statistical significance of chimneys results. Significant differences $(p<0.05)$ between mean levels of all pollutants, except $\mathrm{CO}_{2}$ and $\mathrm{SO}_{2}$, emitted from grilling were found with the other three methods of cooking. It confirms again the role of the grilling process in polluting the indoor and outdoor air. On the other hand, except for grilling restaurants, there is no significant difference $(p>0.05)$ between the control area and areas of frying, cooking, and baking restaurants. This can be explained by the considerable emission of the studied pollutants from the traffic activity.

Mean concentrations of $\mathrm{CO}, \mathrm{NO}_{2}, \mathrm{SO}_{2}$, and VOCs of the outdoor air during this study were compared with their Air Quality Guidelines (AQG) as adopted by the Saudi 
Environmental Law [54] and the WHO guidelines [55] and presented in Table 6. Levels of $\mathrm{CO}$ and $\mathrm{NO}_{2}$ were lower in their AQGs. Levels of VOCs were higher than their AQGs in areas of grilling and frying restaurants, while levels of $\mathrm{SO}_{2}$ exceeded their AQGs in areas of grilling and baking restaurants. This can be easily clarified by the presence of sulfur in both charcoal and diesel fuel which is usually used in baking stoves.

Table 5. One-way ANOVA test for mean levels of pollutants in the outdoor ambient air.

\begin{tabular}{|c|c|c|c|c|c|}
\hline Pollutant & Food Preparation Type & Frying & Cooking & Baking & Control \\
\hline \multirow{4}{*}{$\mathrm{CO}$} & Grilling & $0.000 *$ & $0.000 *$ & 0.000 * & $0.000 *$ \\
\hline & Frying & & 0.965 & 0.976 & 0.934 \\
\hline & Cooking & & & 0.999 & 0.961 \\
\hline & Baking & & & & 0.968 \\
\hline \multirow{4}{*}{$\mathrm{CO}_{2}$} & Grilling & 0.009 & $0.002 *$ & 0.132 & $0.000 *$ \\
\hline & Frying & & 0.569 & 0.870 & 0.044 * \\
\hline & Cooking & & & 0.573 & 0.118 \\
\hline & Baking & & & & 0.082 \\
\hline \multirow{4}{*}{ VOC } & Grilling & $0.000 *$ & $0.000 *$ & 0.000 * & $0.000 *$ \\
\hline & Frying & & $0.033 *$ & 0.124 & 0.085 \\
\hline & Cooking & & & 0.998 & 0.934 \\
\hline & Baking & & & & 0.948 \\
\hline \multirow{4}{*}{$\mathrm{NO}_{2}$} & Grilling & $0.004 *$ & $0.001 *$ & $0.007 *$ & $0.000 *$ \\
\hline & Frying & & 0.677 & 0.000 * & 0.073 \\
\hline & Cooking & & & 0.000 * & 0.145 \\
\hline & Baking & & & & 0.000 * \\
\hline \multirow{4}{*}{$\mathrm{SO}_{2}$} & Grilling & $0.000 *$ & $0.000 *$ & 0.008 & $0.001 *$ \\
\hline & Frying & & 0.993 & 0.987 & 0.555 \\
\hline & Cooking & & & 982 & 556 \\
\hline & Baking & & & & 0.649 \\
\hline
\end{tabular}

* The mean difference is significant at the 0.05 level.

Table 6. Mean levels of pollutants in ambient air compared to their AQGs.

\begin{tabular}{ccccccc}
\hline \multirow{2}{*}{ Pollutant } & \multicolumn{9}{c}{ Mean Concentration of the Study $(\mathbf{p p m})$} & \multirow{2}{*}{$\begin{array}{c}\text { AQG } \\
\text { (ppm) }\end{array}$} \\
\cline { 2 - 5 } & Grilling & Frying & Cooking & Baking & Control & \\
\hline $\mathrm{CO}$ & 5.0 & 2.0 & 2.0 & 3.0 & 2.0 & 9 \\
$\mathrm{NO}_{2}$ & 0.04 & 0.03 & 0.01 & 0.02 & 0.01 & 0.08 \\
$\mathrm{SO}_{2}$ & 0.18 & 0.12 & 0.11 & 0.15 & 0.01 & 0.14 \\
$\mathrm{VOCs}$ & 0.31 & 0.26 & 0.12 & 0.11 & 0.08 & 0.24 \\
\hline
\end{tabular}

However, exact quantification of the contribution of restaurants' emissions to outdoor air is very scarce. Few previous studies were conducted to study the impact of cookstove smoke on ambient air quality. For example, a field study was conducted in four randomly selected households in two rural locations of southern Nepal during April 2017. This study revealed that $66 \%$ of particulate matter is less than 2.5 microns $\left(\mathrm{PM}_{2.5}\right)$ and $80 \%$ of the black carbon emissions from biomass cookstoves directly escape into ambient air [56]. Another study was also conducted in rural Nepal revealed that a range of $6-58 \%$ of the particulate matter emitted from the open design cookstoves is liberated to the outdoor atmosphere [57].

Cooking emissions are produced from the stove used for cooking and the emissions produced by cooking the food itself. Characteristics of both stove and the food being cooked influence cooking emissions type and concentration levels. Emissions from the stove can vary significantly depending on the fuel source [58]. For example, gas burners produce higher particle concentrations, formaldehyde ( $\mathrm{HCHO}), \mathrm{CO}$, and $\mathrm{NO}_{2}$ when compared to electric stoves $[59,60]$. Solid fuel combustion in cookstoves emits a complex mixture of 
particulate and gaseous species, some of these pollutants contribute to levels of commonly regulated pollutants in the ambient environment [61]. Many biomass fuels and coal also contain low concentrations of chlorine that lead to low levels of emissions of dioxins and furans [62]. Besides stove and fuel source characteristics, the type of food, method of cooking, and cooking temperature can also impact the type and intensity of the cooking emission. For example, high-heat cooking activities such as broiling and frying can produce acrolein, polycyclic aromatic hydrocarbons (PAHs), and particulates, while it has also been demonstrated that the process of charbroiling and the practice of cooking fatty foods (such as high-fat hamburgers) yield higher particle emission concentrations compared to lower-heat cooking and low-fat foods [63,64].

Access to clean cooking fuels and technologies is essential for maintaining human health and achieving environmental sustainability, particularly in developing counties. A recent study has been conducted to for the first time the environmental sustainability of household cooking, focusing on remote communities in developing countries in the Southeast Asia-Pacific (SEAP) region and considering both life cycle and local impacts. To guide rural development policies, the impacts of the following cooking fuels were considered: liquefied petroleum gas, kerosene, wood, charcoal, crop residues, biogas, and electricity. Results of the study revealed that biogas from manure is environmentally the most sustainable cooking fuel, while fuelwood is the best option for climate change, with relatively low other impacts, apart from freshwater eutrophication. Cooking using electricity is the worst option since it is typically generated from diesel in off-grid communities. LPG and kerosene have higher resource depletion and land use impacts compared to biomass fuels derived from waste. Solid biomass fuels (fuelwood, charcoal, and crop residues) have high freshwater eutrophication, terrestrial ecotoxicity, and human toxicity. In addition, direct emissions from their combustion cause significant local health and environmental impacts [65].

Many intervention strategies can be used to effectively mitigate the emissions of pollutants from restaurants and protect people's health against the restaurant fumes both inside the restaurant and in its chimneys before discharging their contaminants to the ambient air. For example, separate exhaust systems must be provided to those cooking operations giving rise to oily fume and strong odor emissions and treat the emissions with separate control equipment such as venturi and activated carbon. Control equipment must be installed directly above the stoves and properly connected with the exhaust ducts to prevent cooking fume from leaking through possible cracks. For exhaust outlets near the sensitive receptors, the air pollution problem would still exist even after the application of advanced control technologies. To avoid air nuisance likely caused to the air-sensitive receivers, the owners and operators of the restaurants and food business should refrain from choosing these sites for their business. Suitable siting or positioning of the outlet of the exhaust system is of paramount importance to avoid causing or contributing to air pollution. The exhaust outlet of the restaurant chimney must be installed as high as possible for upward discharge.

\section{Conclusions}

The wide and fast spread of restaurants in all urban areas of the world cannot be dispensed or neglected, particularly in densely populated areas. The emission of pollutants from the restaurant chimneys has a considerable and direct effect on the outdoor ambient air, particularly the grilling process that emits pollutants at a much higher rate than those of the other food cooking methods used in restaurants. Any negative or positive change in the combustion efficiency or the internal cooking process of restaurants will be accompanied by the same change in the outer atmosphere. Fortunately, the combustion chambers and processes in all selected restaurants for this study were working efficiently, and most of the emitted pollutants were lower than their standards. The result of this study is expected to help the decision-makers and regulators to effectively inspect the emissions of pollutants from restaurants for protecting people's health against restaurant fumes and helping the 
restaurants' owners to take the correct actions for reducing levels of air pollution both inside the restaurant and in its chimneys before discharging their contaminants to the outer atmosphere. Furthermore, more studies must be conducted to separately study the effect of each type of fuel that is used in restaurants on the outdoor air quality.

Author Contributions: Methodology, M.F.E. and O.A.I.; formal analysis, M.F.E. and O.A.I.; data curation, M.F.E.; writing — original draft preparation, M.F.E.; writing—review and editing, M.F.E.; supervision, M.F.E.; project administration, M.F.E. All authors have read and agreed to the published version of the manuscript.

Funding: This research received no external funding.

Data Availability Statement: Not applicable.

Conflicts of Interest: The authors declare no conflict of interest.

Ethical Approval: The approval to conduct this study was obtained from the Municipality of the Eastern Province, Saudi Arabia. Each restaurant owner was provided with information about the study and the purpose of the study before conducting any sampling step. All the aspects of the subjects were kept confidential and used only for the study purpose.

\section{References}

1. Po1torak, A.; Wyrwisz, J.; Moczkowska, M.; Marcinkowska-Lesiak, M.; Stelmasiak, A.; Rafalska, U. Microwave vs. convection heating of bovine gluteus Medius muscle: Impact on selected physical properties of final product and cooking yield. Int. J. Food Sci. Technol. 2015, 50, 958-965. [CrossRef]

2. Bansal, M.; Saini, R.P.; Khatod, D.K. Development of cooking sector in rural areas in India-A review. Renew. Sustain. Energy Rev. 2013, 17, 44-53. [CrossRef]

3. İşler, A.; Karaosmanoğlu, F. Traditional cooking fuels, ovens and stoves in Turkey. In Proceedings of the Thirty-First IAEE International Conference, Istanbul, Turkey, 16-17 June 2008.

4. Ramanathan, R.; Ganesh, L.S. A multi-objective analysis of cooking energy alternatives. Energy 1994, 19, 469-478. [CrossRef]

5. Afrane, G.; Ntiamoah, A. Analysis of the life-cycle costs and environmental impacts of cooking fuels used in Ghana. Appl. Energy 2012, 98, 301-306. [CrossRef]

6. World Bank. Household Cookstoves, Environment, Health, and Climate Change: A New Look at an Old Problem; World Bank: Washington, DC, USA, 2011.

7. Jian-li, W.; Jun-bo, Z.; Mao-chu, G.; Zhi-min, L.; Ming, Z.; Yao-qiang, C. Remove cooking fume using catalytic combustion over $\mathrm{Pt} / \mathrm{La}-\mathrm{Al}_{2} \mathrm{O}_{3}$. J. Environ. Sci. 2007, 19, 644-646.

8. Zhang, Z.; Zhao, Y.; Zhou, M.; Tao, P.; Li, R. Measurement of indoor air quality in Chinese charcoal barbecue restaurants. Proc. Eng. 2017, 205, 887-894. [CrossRef]

9. Guo, H. Source apportionment of ambient volatile organic compounds from petroleum and non-petroleum emissions. J. Pet. Environ. Biotechnol. 2012, 3, e112. [CrossRef]

10. Kim, K.H.; Jahan, S.A.; Kabir, E. A review of diseases associated with household air pollution due to the use of biomass fuels. J. Hazard. Mater. 2011, 192, 425-431. [CrossRef]

11. Bhanarkar, A.D.; Majumdar, D.; Nema, P.; George, K.V. Emissions of $\mathrm{SO}_{2}, \mathrm{NOx}$ and particulates from a pipe manufacturing plant and prediction of impact on air quality. Environ. Monit. Assess. 2010, 169, 677-685. [CrossRef] [PubMed]

12. Lee, S.C.; Li, W.; Chan, L.Y. Indoor air quality at restaurants with different styles of cooking in metropolitan Hong Kong. Sci. Total Environ. 2001, 279, 181-193. [CrossRef]

13. Pang, S.; Wong, A. Challenges on the control of cooking fume emissions from restaurants. In Proceedings of the Better Air Quality in Asian and Pacific Rim Cities (BAQ 2002), Hong Kong, 16-18 December 2002.

14. Alves, C.A.; Evtyugina, M.; Cerqueira, M.; Nunes, T.; Duarte, M.; Vicente, E. Volatile organic compounds emitted by the stacks of restaurants. Air Qual. Atmos. Health 2015, 8, 401-412. [CrossRef]

15. Kabir, E.; Kim, K.H. An investigation on hazardous and odorous pollutant emission during cooking activities. J. Hazard. Mater. 2011, 188, 443-454. [CrossRef] [PubMed]

16. Vicente, E.D.; Vicente, A.; Evtyugina, M.; Carvalho, R.; Tarelho, L.A.C.; Oduber, F.I.; Alves, C. Particulate and gaseous emissions from charcoal combustion in barbecue Grills. Fuel Proc. Technol. 2018, 176, 296-306. [CrossRef]

17. Lahiff, M.; Rehfuess, E.A.; Mishra, V.; Smith, K.R. Solid fuel use for household cooking: Country and regional estimates for 1980-2010. Environ. Health Perspect. 2013, 121, 784-790.

18. Johnson, E. Charcoal versus LPG grilling: A carbon-footprint comparison. Environ. Impact Assess. Rev. 2009, 29, 370-378. [CrossRef]

19. Taner, S.; Pekey, B.; Pekey, H. Fine particulate matter in the indoor air of barbeque restaurants: Elemental compositions, sources and health risks. Sci. Total Environ. 2013, 454-455, 79-87. [CrossRef] 
20. Rahman, M.M.; Kim, K.H. Release of offensive odorants from the combustion of barbecue charcoals. J. Hazard. Mater. 2012, 215-216, 233-242. [CrossRef] [PubMed]

21. Susaya, J.; Kim, K.; Ahn, J.; Jung, M.; Kang, C. BBQ charcoal combustion as an important source of trace metal exposure to humans. J. Hazard. Mater. 2010, 176, 932-937. [CrossRef]

22. Lewtas, J. Air pollution combustion emissions: Characterization of causative agents and mechanisms associated with cancer, reproductive, and cardiovascular effects. Mut. Res. 2007, 636, 95-133. [CrossRef]

23. Fitzer, E.; Ochling, K.; Boehm, H.P.; Marsh, H. Recommended terminology for the description of carbon as a solid. Pure Appl. Chem. 1995, 67, 473-506. [CrossRef]

24. Kabir, E.; Kim, K.-H.; Ahn, J.-W.; Hong, O.-F.; Sohn, J.R. Barbecue charcoal combustion as a potential source of aromatic volatile organic compounds and carbonyls. J. Hazard. Mater. 2010, 174, 492-499. [CrossRef]

25. Pandey, S.K.; Kim, K.-H.; Kang, C.H.; Jung, M.C.; Yoon, H. BBQ charcoal as an important source of mercury emission J. Hazard. Mater. 2009, 162, 536-538. [CrossRef]

26. Hsieh, L.T.; Yang, H.H.; Lin, Y.C.; Tsai, C.H. Levels and composition of volatile organic compounds from the electric oven during roasting pork activities. Sustain. Environ. Res. 2012, 2, 17-24.

27. Huang, Y.; Ho, S.S.H.; Ho, K.F.; Lee, S.C.; Yu, J.Z.; Louie, P.K.K. Characteristics and health impacts of VOCs and carbonyls associated with residential cooking activities in Hong Kong. J. Hazard. Mater. 2011, 186, 344-351. [CrossRef]

28. Usinger, J. Manual on Simple Monitoring Techniques for the Control. of Indoor Air and Combustion Quality Standards in Developing Countries, 2nd ed.; Deutsche Gesellschaft für Technische Zusammenarbei: Wiesbaden, Germany, 1999.

29. Chao, C.Y.; Wong, K.K. Residential indoor $\mathrm{PM}_{10}$ and $\mathrm{PM}_{2.5}$ in Hong Kong and the elemental composition. Atmos. Environ. 2002, 36, 265-277. [CrossRef]

30. Sweeney, L.M.; Sommerville, D.R.; Goodwin, M.R.; James, R.A.; Channel, S.R. Acute toxicity when concentration varies with time: A case study with carbon monoxide inhalation by rats. Regul. Toxicol. Pharm. 2016, 80, 102-115. [CrossRef]

31. Kleeman, M.J.; Schauer, J.J.; Cass, G.R. Size and composition distribution of fine particulate matter emitted from wood burning, meat charbroiling, and cigarettes. Environ. Sci. Technol. 1999, 33, 3516-3523. [CrossRef]

32. Nolte, C.G.; Schauer, J.J.; Cass, G.R.; Simoneit, B.R.T. Highly polar organic compounds present in meat smoke. Environ. Sci. Technol. 1999, 33, 3313-3316. [CrossRef]

33. Maes, W.H.; Verbist, B. Increasing the sustainability of household cooking in developing countries: Policy implications Renew. Sustain. Energy Rev. 2012, 16, 4204-4221. [CrossRef]

34. Rehfuess, E.; Tzala, L.; Best, N.; Briggs, D.J.; Joffe, M. Solid fuel use and cooking practices as a major risk factor for ALRI mortality among African children. J. Epid. Community Health 2009, 63, 887-892. [CrossRef]

35. MacCarty, N.; Still, D.; Ogle, D. Fuel use and emissions performance of fifty cooking stoves in the laboratory and related benchmarks of performance. Energy Sustain. Develop. 2010, 14, 161-171. [CrossRef]

36. Ballard-Tremeer, G.; Mathee, A. Review of Interventions to Reduce the Exposure of Women and Young Children to Indoor Air Pollution in Developing Countries; WHO/USAID Global Consultation: Washington, DC, USA, 2000.

37. Budds, J.; Biran, A.; Rouse, J. What's Cooking? A Review of Health Impacts of Indoor air Pollution and Technical Interventions for Its Reduction; Leicser; Water and Environmental Health at London and Loughborough (WELL): London, UK, 2001.

38. Probert, D.; Newborough, M. Designs, thermal performances and other factors concerning cooking equipment and associated facilities. Appl. Energy 1985, 21, 81-222. [CrossRef]

39. Kshirsagar, M.P.; Kalamkar, V.R. A comprehensive review on biomass cook stoves and a systematic approach for modern cook stove design. Renew. Sustain. Energy Rev. 2014, 30, 580-603. [CrossRef]

40. Parmigiani, S.P.; Vitali, F.; Lezzi, A.M.; Vaccari, M. Design and performance assessment of a rice husk fueled stove for household cooking in a typical sub-Saharan setting. Energy Sustain. Develop. 2014, 23, 15-24. [CrossRef]

41. Xu, Z.; Sun, D.-W.; Zhang, Z.; Zhu, Z. Research developments in methods to reduce carbon footprint of cooking operations: A review. Trends Food Sci. Technol. 2015, 44, 49-57. [CrossRef]

42. Prapas, J.; Baumgardner, M.E.; Marchese, A.J.; Willson, B.; DeFoort, M. Influence of chimneys on combustion characteristics of buoyantly driven biomass stoves. Energy Sustain. Develop. 2014, 23, 286-293. [CrossRef]

43. El Sharkawy, M.; Javed, W. Study of indoor air quality level in various restaurants in Saudi Arabia. Environ. Prog. Sustain. Energy 2018, 37, 1713-1721. [CrossRef]

44. Svendsen, K.; Jensen, H.N.; Sivertsen, I.; Sjaastad, A.K. Exposure to cooking fumes in restaurant kitchens in Norway. Ann. Occup. Hyg. 2002, 46, 395-400. [PubMed]

45. Chiang, C.M.; Lai, C.M.; Chou, P.C.; Li, Y.Y. The influence of an architectural design alternative (transoms) on indoor air environment in conventional kitchens in Taiwan. Build. Environ. 2000, 35, 579-585. [CrossRef]

46. Environment Protection Agency (EPA). Air Emissions Monitoring Guidance Note \#2 (AG2); EPA, Office of Environmental Enforcement (OEE): Wexford, Ireland, 2007.

47. Huang, H.L.; Lee, W.M.G.; Wu, F.S. Emissions of air pollutants from indoor charcoal barbecue. J. Hazard. Mater. 2016, 302, 198-207. [CrossRef]

48. Sung-OK, B.; Kim, Y.-S.; Perry, R. Indoor air quality in homes, offices and restaurants in Korean urban areas-indoor/outdoor relationships. Atmos. Environ. 1997, 31, 529-544. 
49. Benfenati, E.; Pierucci, P.; Niego, D. A case study of indoor pollution by Chinese cooking. Toxic Environ. Chem. 1998, 65, 217-224. [CrossRef]

50. Central Pollution Control Board. Guidelines for Continuous Emission Monitoring Systems; East Arjun Nagar: Delhi, India, 2018.

51. The Ministry of Environment. Revised Standards for Coal-Based Thermal Power Plants, India. 2017. Available online: http: //www.indiaenvironmentportal.org.in/content/423111/revised-standards-for-coal-based-thermal-power-plants (accessed on 10 May 2021).

52. Sloss, L.L. Emissions and effects of air toxics from coal combustion: An overview. In Proceedings of the Managing Hazardous Air Pollutants: State of the Art, Washington, DC, USA, 13-15 July 1993.

53. Licata, A.; Hartenstein, H.U.; Terracciano, L. Comparison of U.S. EPA and European Emission Standards for Combustion and Incineration Technologies. Columbia. 1997. Available online: http://www.seas.columbia.edu/earth/wtert/newwtert/Research/ sofos/nawtec/nawtec05/nawtec05-48.pdf (accessed on 10 May 2021).

54. Royal Commission for Jubail and Yanbu; Royal Commission Environmental Regulations: Jubail, Kingdom of Saudi Arabia, 2015; Volume 1.

55. World Health Organization. Guidelines for Air Quality; WHO: Geneva, Switzerland, 2001.

56. Adhikari, S.; Mahapatra, P.S.; Pokheral, C.P.; Puppala, S.P. Cookstove smoke impact on ambient air quality and probable consequences for human health in rural locations of southern Nepal. Int. J. Environ. Res. Public Health 2020, 17, 550. [CrossRef] [PubMed]

57. Soneja, S.I.; Tielsch, J.M.; Curriero, F.C.; Zaitchik, B.; Khatry, S.K.; Yan, B.; Chillrud, S.N.; Breysse, P.N. Determining particulate matter 1 and black carbon exfiltration estimates for traditional cookstove use in rural Nepalese village households. Environ. Sci. Technol. 2015, 49, 5555-5562. [CrossRef]

58. Wong, G.W.; Brunekreef, B.; Ellwood, P.; Anderson, H.R.; Asher, M.I.; Crane, J.; Lai, C.K.W. Cooking fuels and prevalence of asthma: A global analysis of phase three of the international study of asthma and allergies in childhood (ISAAC). Lancet Respir. Med. 2013, 1, 386-394. [CrossRef]

59. Amouei Torkmahalleh, M.; Gorjinezhad, S.; Unluevcek, H.S.; Hopke, P.K. Review of factors impacting emission/ concentration of cooking generated particulate matter. Sci. Total Environ. 2017, 586, 1046-1056. [CrossRef]

60. Garrett, M.H.; Hooper, M.A.; Hooper, B.M.; Abramson, M.J. Respiratory symptoms in children and indoor exposure to nitrogen dioxide and gas stoves. Am. J. Respir. Crit. Care Med. 1998, 158, 891-895. [CrossRef] [PubMed]

61. Cardenas, B.; Umlauf, G.; Maiz, P.; Mariani, G.; Skejo, H.; Blanco, S. PCDD/F, PCB and HCB emissions from rural wood stoves: A preliminary evaluation in Mexico. Organohalog. Compd. 2010, 72, 1511-1513.

62. Northcross, A.L.; Katharine, H.S.; Canuz, E.; Smith, K.R. Dioxin inhalation doses from wood combustion in indoor cookfires. Atmos. Environ. 2012, 49, 415-418. [CrossRef]

63. Abdullahi, K.L.; Delgado-Saborit, J.M.; Harrison, R.M. Emissions and indoor concentrations of particulate matter and its specific chemical components from cooking: A review. Atmos. Environ. 2013, 71, 260-294. [CrossRef]

64. Seltenrich, N. Take Care in the Kitchen: Avoiding Cooking-Related Pollutants. Environ. Health Perspect. 2014, 122, A154-A159. [CrossRef] [PubMed]

65. Aberilla, J.M.; Gallego-Schmid, A.; Stamford, L.; Azapagic, A. Environmental sustainability of cooking fuels in remote communities: Life cycle and local impacts. Sci. Total Environ. 2020, 713, 136445. [CrossRef] [PubMed] 